\title{
Altered expression of the PLAGL1 (ZAC1/LOT1) gene in colorectal cancer: Correlations to the clinicopathological parameters
}

\author{
ANNA E. KOWALCZYK ${ }^{1}$, BARTLOMIEJ E. KRAZINSKI ${ }^{1}$, JANUSZ GODLEWSKI ${ }^{1}$, JOLANTA KIEWISZ ${ }^{1}$, \\ PRZEMYSLAW KWIATKOWSKI $^{1}$, AGNIESZKA SLIWINSKA-JEWSIEWICKA ${ }^{1}$, JACEK KIEZUN ${ }^{1}$, \\ PIOTR M. WIERZBICKI ${ }^{2}$, GABRIEL BODEK ${ }^{3}$, MARIAN SULIK $^{4}$ and ZBIGNIEW KMIEC ${ }^{1,2}$ \\ ${ }^{1}$ Department of Human Histology and Embryology, Faculty of Medical Sciences, University of Warmia and Mazury, \\ 10-082 Olsztyn; ${ }^{2}$ Department of Histology, Medical University of Gdansk, 80-210 Gdansk; \\ ${ }^{3}$ In Vitro and Cell Biotechnology Laboratory, Institute of Animal Reproduction and Food Research, \\ Polish Academy of Sciences, 10-243 Olsztyn; ${ }^{4}$ Department of Pathomorphology, \\ Faculty of Medical Sciences, University of Warmia and Mazury, 10-561 Olsztyn, Poland
}

Received April 23, 2015; Accepted June 2, 2015

DOI: $10.3892 /$ ijo.2015.3067

\begin{abstract}
Pleomorphic adenoma gene-like 1 gene (PLAGL1) encodes a zinc-finger nuclear transcription factor which promotes apoptosis and cell cycle arrest. Loss or downregulation of its expression has been observed in various human neoplasms. This study compared PLAGL1 expression in colorectal cancer (CRC) tissue and colon mucosa of healthy subjects at the mRNA and protein levels, and estimated its prognostic value. The PLAGL1 mRNA levels were also determined in CRC cell lines. We collected paired tumor tissue and unchanged mucosa of the large intestine from $121 \mathrm{CRC}$ patients as well as 72 colon biopsies of healthy subjects obtained during screening colonoscopy. PLAGL1 mRNA levels were determined by quantitative PCR, while PLAGL1 protein expression was estimated by western blotting and immunohistochemistry. PLAGL1 mRNA level in tumor tissue was 2-fold lower than in samples of corresponding unchanged tissues and biopsies of healthy colon mucosa. Downregulated expression of PLAGLI mRNA was also observed in all tested CRC cell lines. Although the average content of PLAGL1 protein did not differ significantly between tumor and unchanged tissues of CRC patients or colon mucosa of healthy individuals, the decreased PLAGL1 protein levels in tumor specimens correlated with lymph node involvement, the presence of metastases and higher TNM disease stage. The PLAGL1 expression level did not corre-
\end{abstract}

Correspondence to: Dr Anna Kowalczyk, Department of Human Histology and Embryology, Faculty of Medical Sciences, University of Warmia and Mazury, 30 Warszawska Str., 10-082 Olsztyn, Poland E-mail: a.kowalczyk@uwm.edu.pl

Key words: PLAGL1 expression, colorectal cancer, healthy colon mucosa, clinicopathological parameters, survival, qPCR, western blotting, IHC late significantly with patient overall survival; however, the hazard ratio for patients whose tumor tissues showed reduced PLAGL1 immunohistochemical staining was twice higher than in patients with increased PLAGL1 immunoreactivity. In conclusion, these results suggest that dysregulation of PLAGL1 expression may be involved to some extent in the progression of CRC, but the so far collected patient survival data do not confirm applicability of the PLAGL1 expression level as a prognostic factor in CRC.

\section{Introduction}

Colorectal cancer (CRC) is the third most common cancer in men and the second in women worldwide (1). The main cause of death in CRC patients is distant metastasis. Identification of factors and mechanisms underlying CRC development and progression, as well as detection of early-stage disease markers could effectively prevent death from CRC.

Alterations in genes are one of the mainsprings of CRC. This includes inactivation of tumor suppressor genes by genetic and epigenetic mechanisms. Tumor suppressor genes are typically inactivated by mutation, deletion, or promoter methylation which silences gene expression (2). Pleomorphic adenoma gene-like 1 gene ( $P L A G L 1$, also known as ZAC1 or $L O T 1)$ is the candidate tumor suppressor gene that encodes a protein with antiproliferative activity which is due to the induction of apoptosis and cell cycle arrest (3).

PLAGL1 is widely expressed in normal tissues (4), and localized on chromosome 6q24-25, a region maternally imprinted (5), and frequently deleted in many tumors (6). It was shown that PLAGL1 may be transcriptionally silenced by DNA methylation of $\mathrm{CpG}$ islands and histone deacetylation (5). Altered expression of PLAGL1 gene was observed in several types of human cancers and tumor-derived cell lines such as breast $(7)$, ovary $(8,9)$, and prostate tumors $(10)$, as well as in nonfunctioning pituitary adenomas (11), head and neck squamous 
cell carcinoma (12), and basal cell carcinoma (6). Expression profiling of colorectal samples of CRC patients with cDNA microarrays also demonstrated altered expression of PLAGL1 mRNA in CRC as compared to proximal non-cancerous colorectal mucosa (13), but there is no previous comparison of PLAGL1 expression in CRC tissue and colon mucosa of healthy subjects at the mRNA and protein levels. Moreover, the prognostic value of the PLAGL1 expression level in CRC progression and patient survival remains unknown. Therefore, the main objective of our study was to analyze and compare PLAGL1 gene expression in samples of tumor and unchanged colorectal tissues of CRC patients as well as in mucosal colon biopsies in a group of healthy subjects by quantitative realtime PCR (qPCR), western blotting and immunohistochemical (IHC) techniques. Furthermore, we have examined levels of PLAGL1 mRNA in CRC cell lines. To estimate the prognostic significance of the PLAGL1 expression level, we analyzed correlations between the expression level of PLAGL1 and clinicopathological features of CRC patients, as well as the overall survival of the patients.

\section{Materials and methods}

Ethics. This study was performed in accordance with the ethical standards, and approved by the Bioethics Committee of the University of Warmia and Mazury in Olsztyn (decision no. 3/2010 and 34/2010), and informed written consent regarding the use of tissue was obtained from each patient included in the study.

Patients and collection of colorectal samples. The specimens were collected at the Hospital of the Ministry of Internal Affairs and Administration in Olsztyn from 2010 to 2013. The study included 121 patients with CRC (demographic and clinicopathological data are presented in Table I). None of the CRC patients had a second neoplastic disease or had previously undergone chemo- or radiotherapy. The control group consisted of 72 healthy individuals ( 24 males and 48 females, average age $57.2 \pm 6.65$ years, range $36-82$ years; mean $\pm S D$ ) who underwent colonoscopy as a part of a routine screening for CRC (within the National screening program for early detection of colorectal cancer). Control subjects had no family history of CRC. None of the CRC patients or control subjects suffered from inflammatory bowel disease. Clinical and demographic data were obtained at the time of enrollment. Data on the overall survival were collected for all patients. Median follow-up time was 36.1 months.

CRC samples were obtained during the partial surgical resection of the large intestine, and control group specimens were collected during colonoscopy. In CRC patient group, two types of matched samples were taken within $20 \mathrm{~min}$ after tumor resection: i) tumor tissue and ii) macroscopically unchanged mucosa from a distant part of resected large intestine. Specimens were immediately cut in two pieces for qPCR and western blot analyses, frozen in liquid nitrogen, and stored at $-80^{\circ} \mathrm{C}$, whereas for routine histological evaluation and immunohistochemistry, the samples were fixed in $10 \%$ neutral buffered formalin and further processed into paraffin blocks. In the control group of healthy patients, one biopsy was fixed in $10 \%$ neutral buffered formalin for routine histological examination, and two specimens from the adjacent location to the biopsy site were collected for qPCR or western blot assays.

Cell lines. Human CRC cell lines with different characteristics (HT-29, SW-480, LoVo) (14) and a control line, the CCD 841 CoN cell line (epithelial-like, established from normal colonic tissue) were purchased from the American Type Culture Collection (ATCC; Manassas, VA, USA). Cells were cultured under conditions recommended by the manufacturer, and were harvested at $\sim 80 \%$ confluence.

Total RNA extraction and reverse transcription. Total RNA was extracted from cell lines as well as paired samples of cancer tissue and unchanged mucosa derived from 121 CRC patients and 40 colonoscopic biopsies of healthy subjects using a Total RNA Prep Plus kit (A\&A Biotechnology, Gdynia, Poland), following the manufacturer's protocol. Isolated RNA was quantified with spectrophotometry (NanoDrop 1000, NanoDrop products, Wilmington, DE, USA). Reverse transcription was carried out in a vial containing $20 \mu 1$ reaction mixture of $2 \mu \mathrm{g}$ of total RNA, $0.5 \mu \mathrm{g}$ of oligo dT primers (Sigma-Aldrich, St. Louis, MO, USA), 200 U of RevertAid ${ }^{\text {TM }}$ Reverse Transcriptase, 20 U of RiboLock ${ }^{\mathrm{TM}}$ RNase inhibitor, and $1 \mathrm{mM}$ of each dNTP (all Thermo Scientific, Waltham, MA, USA). Reactions were performed according to the manufacturer's instructions, and resulting complementary DNAs (cDNAs) were stored at $-20^{\circ} \mathrm{C}$ after 10 -fold dilution with nuclease-free water to be used as the template in qPCR analysis.

Real-time quantitative PCR. Quantification of PLAGL1 gene expression was carried out using ABI 7500/7500 Fast RealTime PCR system (Life Technologies, Applied Biosystems, Foster City, CA, USA). Hypoxanthine phosphoribosyltransferase 1 (HPRT1) gene was used as an internal control to normalize the transcript levels of PLAGL1. The levels of PLAGL1 and HPRT1 cDNAs in collected isolates were determined using TaqMan ${ }^{\circledR}$ Fast Advanced Master Mix and a respective TaqMan ${ }^{\circledR}$ Gene Expression assay (all from Life Technologies, Applied Biosystems) according to the manufacturer's instructions. The primers and TaqMan probes used were PLAGL1: Hs00414677_m1, and HPRT1: Hs02800695_m1. All samples were amplified in duplicates using the following conditions: polymerase activation for $20 \mathrm{sec}$ at $95^{\circ} \mathrm{C}$, followed by 40 cycles of denaturation at $95^{\circ} \mathrm{C}$ for $3 \mathrm{sec}$ and annealing/ extension at $60^{\circ} \mathrm{C}$ for $30 \mathrm{sec}$. No template control reactions were performed for each qPCR run. Standard curves consisting of serial dilutions of the appropriate cDNA were used to control the efficiency of qPCR reactions. Relative quantification of PLAGL1 expression was evaluated using the $\triangle \Delta \mathrm{Ct}$ method (15). The fold change in the relative PLAGLI gene expression was determined by calculating the $2^{-\Delta \Delta C t}$ value. Fold increase above $1\left(2^{-\Delta \Delta \mathrm{Ct}}>1\right)$ indicated PLAGL1 overexpression in CRC tissue, and fold decrease under $1\left(2^{-\Delta \Delta C_{t}}<1\right)$ indicated PLAGL1 downregulation.

Protein extraction and western blot analysis. Paired samples of tumor tissue and unchanged mucosa derived from 95 CRC patients and 32 colonoscopic biopsies were homogenized in RIPA lysis buffer supplied with 1:100 protease inhibitor 
Table I. Demographic and clinicopathological characteristics of studied CRC patients.

\begin{tabular}{|c|c|c|}
\hline Parameter & No. of cases & Percentage $(\%)$ \\
\hline Total & 121 & 100.0 \\
\hline \multicolumn{3}{|l|}{ Gender } \\
\hline Male & 67 & 55.4 \\
\hline Female & 54 & 44.6 \\
\hline \multicolumn{3}{|l|}{ Age (years) } \\
\hline$\leq 67$ & 60 & 49.6 \\
\hline$>67$ & 61 & 50.4 \\
\hline \multicolumn{3}{|l|}{ Localization } \\
\hline $\begin{array}{l}\text { Cecum, ascending, } \\
\text { and transverse colon }\end{array}$ & 44 & 36.4 \\
\hline $\begin{array}{l}\text { Descending and } \\
\text { sigmoid colon }\end{array}$ & 29 & 24.0 \\
\hline Rectum & 48 & 39.7 \\
\hline \multicolumn{3}{|l|}{$\begin{array}{l}\text { Depth of invasion } \\
\text { (pT status) }\end{array}$} \\
\hline $\mathrm{T} 1$ & 4 & 3.3 \\
\hline $\mathrm{T} 2$ & 16 & 13.2 \\
\hline $\mathrm{T} 3$ & 80 & 66.1 \\
\hline $\mathrm{T} 4$ & 21 & 17.4 \\
\hline \multicolumn{3}{|l|}{$\begin{array}{l}\text { Lymph nodes } \\
\text { (pN status) }\end{array}$} \\
\hline N0 & 63 & 52.1 \\
\hline $\mathrm{N} 1$ & 38 & 31.4 \\
\hline $\mathrm{N} 2$ & 20 & 16.5 \\
\hline \multicolumn{3}{|l|}{$\begin{array}{l}\text { Metastasis } \\
\text { (pM status) }\end{array}$} \\
\hline M0 & 106 & 87.6 \\
\hline M1 & 15 & 12.4 \\
\hline \multicolumn{3}{|l|}{ TNM stage } \\
\hline I & 18 & 14.9 \\
\hline II & 41 & 33.9 \\
\hline III & 47 & 38.8 \\
\hline IV & 15 & 12.4 \\
\hline
\end{tabular}

cocktail, 1:100 phosphatase inhibitor cocktail 2 and $5 \mathrm{mM}$ EDTA (all from Sigma-Aldrich). Homogenates were briefly centrifuged to remove tissue debris. Then, samples were centrifuged twice at $9,000 \mathrm{xg}$ for $10 \mathrm{~min}$ at $4^{\circ} \mathrm{C}$. After centrifugation, supernatants were collected and the total protein content was determined by the Bradford method (16). Samples were aliquoted and stored at $-80^{\circ} \mathrm{C}$ until further analyses.

To determine the level of PLAGL1 protein in tissue lysates, the SDS-PAGE followed by western blotting assays were performed. Isolated protein samples were denatured for $5 \mathrm{~min}$ at $95^{\circ} \mathrm{C}$ and loaded on polyacrylamide gel (40 $\left.\mu \mathrm{g} / \mathrm{lane}\right)$. Gels were run at the $10 \mathrm{~mA} / \mathrm{gel}$ during migration in the stacking gel and $15 \mathrm{~mA} / \mathrm{gel}$ in the separating gel (10\%). Proteins were transferred onto PVDF membrane (western blotting membrane, Roche, Mannheim, Germany). Blots were blocked in 5\% non-fat dry milk dissolved in Tris-buffered saline $\mathrm{pH} 7.5$ with $0.1 \%$ Tween-20 (TBS-T) followed by overnight incubation at $4^{\circ} \mathrm{C}$ with respective primary antibody. Rabbit anti-human monoclonal antibodies against PLAGL1/ZAC (diluted 1:1,000 in TBS-T; \#ab129063, Abcam, Cambridge, UK), and polyclonal antibodies anti-actin (ACTB; 1:100; \#A2066, Sigma-Aldrich) were used. ACTB level was used as the internal protein load control. After the incubation, primary antibodies were washed out with TBS-T. Then, the membranes were treated with the specific HPR-conjugated goat anti-rabbit IgG secondary antibodies (1:40,000; \#A0545, Sigma-Aldrich) for $90 \mathrm{~min}$ at room temperature (RT), developed with an enhanced chemiluminescence (SuperSignal West Pico Chemiluminescent Substrate, Thermo Scientific), and visualized with G:BOX iChemi XR imaging system (Syngene, Cambridge, UK). For the negative control, a primary antibody was omitted and substituted with phosphate-buffered saline (PBS). Protein extracts from 293T cells or HeLa cells (both from Abcam) were used as the positive controls for PLAGL1 immunoblotting. Molecular weight standard (Spectra Multicolor Broad Range Protein Ladder, Thermo Scientific) was included into each blotting experiment to confirm the molecular weight of detected bands. Band intensity was quantified using ImageJ software $(\mathrm{NIH}$, Bethesda, MD, USA) (17).

PLAGL1 protein optical density (OD) was normalized on the basis of ACTB protein OD. OD ratios between tumor and the corresponding unchanged tissue of CRC patients were calculated. The ratios $>1$ indicated that the expression of PLAGL1 protein was upregulated in CRC tissue while those $<1$ were regarded as downregulated.

Immunohistochemistry. PLAGL1 immunoreactivity was analyzed in matched tumor and unchanged colorectal tissues of $60 \mathrm{CRC}$ patients. Immunohistochemistry was performed on $4-\mu$ m-thick paraffin sections. Sections were subjected to antigen retrieval procedure by microwaving for $20 \mathrm{~min}$ in retrieval solution buffer, $\mathrm{pH} 6.0$ (Leica, Wetzlar, Germany), followed by the incubation in $3 \% \mathrm{H}_{2} \mathrm{O}_{2}$ in methanol for $10 \mathrm{~min}$, and next in $2.5 \%$ normal horse serum (Vector Laboratories, Burlingame, CA, USA) for $30 \mathrm{~min}$. The sections were incubated overnight at $4^{\circ} \mathrm{C}$ with rabbit anti-human monoclonal antibody against PLAGL1/ZAC (diluted 1:2,000 in PBS; \#ab129063, Abcam). After washing with PBS, the sections were treated with HRP-conjugated secondary antibody (readyto-use dilution; ImmPRESS Universal reagent Anti-Mouse/ Rabbit Ig, Vector Laboratories) for $30 \mathrm{~min}$ at RT. Then, the sections were immersed in 3',3'-diaminobenzidine (DAB; Dako, Glostrup, Denmark), counterstained with Harris' haematoxylin (Sigma-Aldrich), dehydrated in ethanol, cleared in xylene, and mounted with DPX (Sigma-Aldrich). For each set of staining, the negative controls were performed by omitting the primary antibody.

The PLAGL1 immunostained sections were evaluated using Olympus BX41 light microscope (Olympus, Tokyo, Japan) by an independent pathologist in a blinded manner regarding the clinical data of the patients. Immunoreactivity of PLAGL1 was assessed in cancer cells of CRC sections and 
Table II. Associations between demographic and clinicopathological features of studied CRC patients and the relative mRNA expression of PLAGLI in colorectal tumor tissues.

\begin{tabular}{|c|c|c|c|c|c|c|c|}
\hline \multirow[b]{2}{*}{ Parameter } & \multirow[b]{2}{*}{$\begin{array}{l}\text { No. of } \\
\text { cases }\end{array}$} & \multirow[b]{2}{*}{$\begin{array}{l}\text { Percentage } \\
\quad(\%)\end{array}$} & \multicolumn{4}{|c|}{$\begin{array}{l}\text { PLAGL1 mRNA levels in tumor vs. } \\
\text { unchanged tissues of CRC patients }\end{array}$} & \multirow[b]{2}{*}{ p-values } \\
\hline & & & $\begin{array}{c}\text { Down } \\
(\text { ratio }<1)\end{array}$ & $\begin{array}{l}\text { Percentage } \\
\quad(\%)\end{array}$ & $\begin{array}{l}\mathrm{Up} \\
(\text { ratio }>1)\end{array}$ & $\begin{array}{l}\text { Percentage } \\
\quad(\%)\end{array}$ & \\
\hline Total & 121 & 100.0 & 87 & 71.9 & 34 & 28.1 & \\
\hline \multicolumn{8}{|l|}{ Gender } \\
\hline Male & 67 & 55.4 & 52 & 77.6 & 15 & 22.4 & 0.1548 \\
\hline Female & 54 & 44.6 & 35 & 64.8 & 19 & 35.2 & \\
\hline \multicolumn{8}{|l|}{ Age (years) } \\
\hline$\leq 67$ & 60 & 49.6 & 40 & 66.7 & 20 & 33.3 & 0.2295 \\
\hline$>67$ & 61 & 50.4 & 47 & 77.0 & 14 & 23.0 & \\
\hline \multicolumn{8}{|l|}{ Localization } \\
\hline $\begin{array}{l}\text { Cecum, ascending, } \\
\text { and transverse colon }\end{array}$ & 44 & 36.4 & 32 & 72.7 & 12 & 27.3 & 0.0800 \\
\hline $\begin{array}{l}\text { Descending and } \\
\text { sigmoid colon }\end{array}$ & 29 & 24.0 & 25 & 86.2 & 4 & 13.8 & \\
\hline Rectum & 48 & 39.7 & 30 & 62.5 & 18 & 37.5 & \\
\hline \multicolumn{8}{|l|}{$\begin{array}{l}\text { Depth of invasion } \\
\text { (pT status) }\end{array}$} \\
\hline $\mathrm{T} 1+\mathrm{T} 2$ & 20 & 16.5 & 13 & 65.0 & 7 & 35.0 & 0.5864 \\
\hline $\mathrm{T} 3+\mathrm{T} 4$ & 101 & 83.5 & 74 & 73.3 & 27 & 26.7 & \\
\hline \multicolumn{8}{|l|}{$\begin{array}{l}\text { Lymph nodes } \\
\text { (pN status) }\end{array}$} \\
\hline No & 63 & 52.1 & 42 & 66.7 & 21 & 33.3 & 0.2259 \\
\hline $\mathrm{N} 1+\mathrm{N} 2$ & 58 & 47.9 & 45 & 77.6 & 13 & 22.4 & \\
\hline \multicolumn{8}{|l|}{$\begin{array}{l}\text { Metastasis } \\
\text { (pM status) }\end{array}$} \\
\hline M0 & 106 & 87.6 & 75 & 70.8 & 31 & 29.2 & 0.5533 \\
\hline M1 & 15 & 12.4 & 12 & 80.0 & 3 & 20.0 & \\
\hline \multicolumn{8}{|l|}{ TNM stage } \\
\hline I+II & 59 & 48.8 & 39 & 66.1 & 20 & 33.9 & 0.3484 \\
\hline III+IV & 62 & 51.2 & 48 & 77.4 & 14 & 22.6 & \\
\hline
\end{tabular}

enterocytes of the unchanged colon mucosa using the scale based on the reaction intensity $(0$, no reaction; $10, \leq 10 \% ; 30$, $11-30 \%$; 60, 31-60\%; 80, 61-80\% and 100, >80\%). Ratios in PLAGL1 score between tumor cells and cells of the matched unchanged tissue of CRC patients were calculated. The ratios $>1$ indicated that the immunoreactivity of PLAGL1 in CRC tissue was upregulated while those $<1$ were regarded as downregulated.

Statistical analyses. Statistical analyses were performed using Prism 6 (GraphPad, La Jolla, CA, USA) and Statistica v.10 (StatSoft, Tulsa, OK, USA) software. The differences in mRNA and protein levels between matched tumor and unchanged samples of CRC patients were examined by the Wilcoxon matched-pairs test, whereas differences between colon mucosa biopsies of healthy subjects and tissues of CRC patients as well as between cell lines were assessed by the Mann-Whitney U test. The correlations between the demographic, clinicopathological, and molecular parameters were analyzed by the Fisher's exact and Chi-square tests and confirmed using the Mann-Whitney U test and Kruskal-Wallis test. Survival curves were plotted using Kaplan-Meier method. The statistical significance of differences in survival between groups of patients was evaluated using the log-rank test and confirmed by Cox regression method. In all the analyses, results were considered statistically significant when $\mathrm{p}<0.05$. 


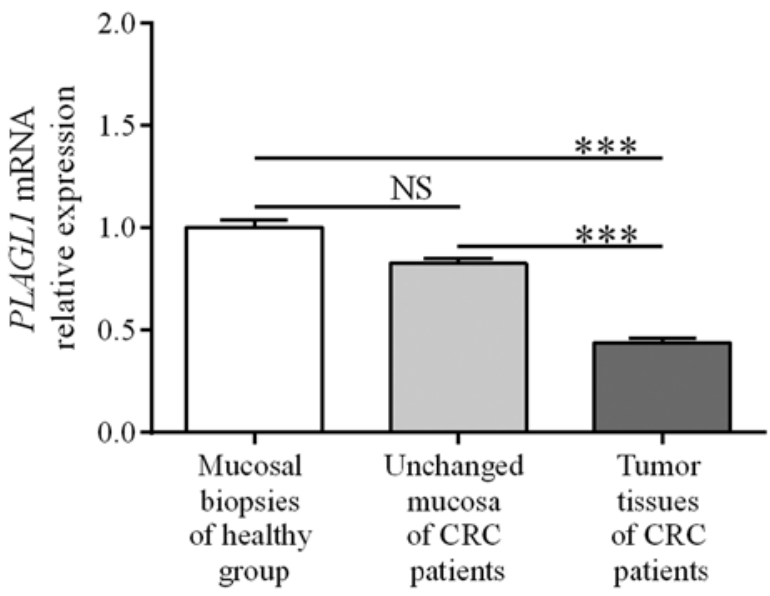

Figure 1. PLAGL1 mRNA levels in the tumor and unchanged large-intestine tissues of CRC patients and colon mucosa of healthy subjects. Expression of PLAGL1 mRNA (mean \pm SEM) is shown in relation to the value obtained for healthy controls (1.0). ${ }^{* * *} \mathrm{p}<0.001$; NS, differences not statistically significant $(\mathrm{p}>0.05)$.

\section{Results}

PLAGL1 mRNA expression in CRC tissues and cell lines is downregulated. To determine the expression of $P L A G L 1$ at the mRNA level, matched tumor and unchanged tissues derived from CRC patients and colonic biopsies of healthy group were subjected to qPCR analysis. PLAGL1 mRNA was found in all studied tissue samples of CRC patients and colonic biopsies of healthy individuals. Among the 121 tumor specimens tested, the relative PLAGL1 mRNA level (tumor tissue vs. matching unchanged mucosa of CRC patients) was decreased in $87(71.9 \%)$ tumors while it was increased in $34(28.1 \%)$ cases (Table II). The expression of PLAGL1 mRNA was significantly decreased in the tumor tissues when compared to unchanged tissue of CRC patients and the colon mucosa of healthy individuals $(0.44 \pm 0.02$ vs. $0.83 \pm 0.02$ and $1.00 \pm 0.04$, respectively; $\mathrm{p}<0.0001$; Fig. 1). The levels of PLAGL1 mRNA in unchanged tissues of CRC patients did not differ significantly from those in colonic biopsies of the healthy group (0.83 \pm 0.02 vs. $1.00 \pm 0.04$; $\mathrm{p}>0.05$; Fig. 1$)$.

QPCR analysis was also used to determine the expression of PLAGL1 gene in CRC cell lines and the control line established from normal colonic tissue. PLAGL1 mRNA levels in HT-29, LoVo and SW-480 cells were significantly lower than those in the CCD $841 \mathrm{CoN}$ cell line $(0.0004 \pm 0.0003$, $0.024 \pm 0.0006$ and $0.047 \pm 0.0087$, respectively, vs. $1.00 \pm 0.0087$; $\mathrm{p}<0.05$; Fig. 2). Among the CRC cell lines the lowest level of PLAGL1 expression was observed in HT-29 cells $(\mathrm{p}<0.05$; Fig. 2). The level of PLAGL1 mRNA in the LoVo cell line was significantly lower than that in SW480 cells (p<0.05; Fig. 2).

The lack of correlation between PLAGL1 mRNA expression in CRC and demographic or clinicopathological features. To assess the impact of PLAGL1 expression at the mRNA level on CRC pathogenesis, the relationships between PLAGLI mRNA content and selected demographic and clinicopathological parameters were tested (Table II). The relative PLAGLI mRNA level did not correlate with the parameters gender,

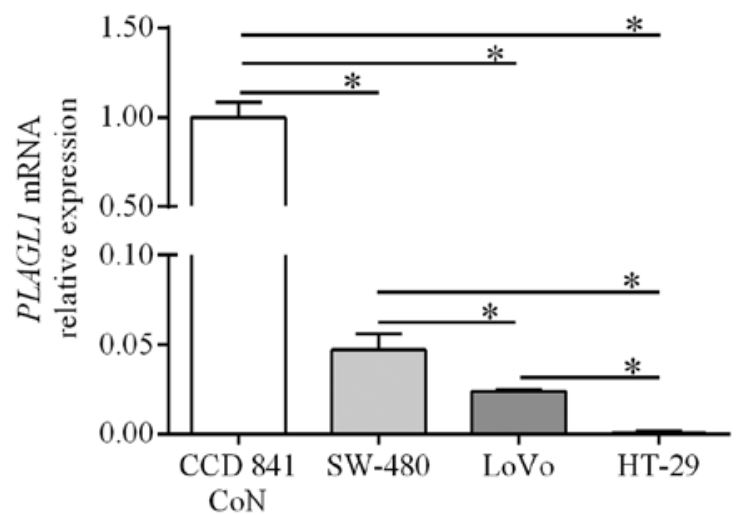

Figure 2. PLAGL1 mRNA levels in selected CRC cell lines (HT-29, LoVo, SW-480) and a control colon epithelium-derived cell line - CCD $841 \mathrm{CoN}$. Expression of PLAGL1 mRNA (mean \pm SEM) is shown in relation to the value obtained for a control cell line (1.0). The experiment was repeated four times for CRC cell lines and five times for a control cell line. ${ }^{*} \mathrm{p}<0.05$.

\section{PLAGL1}

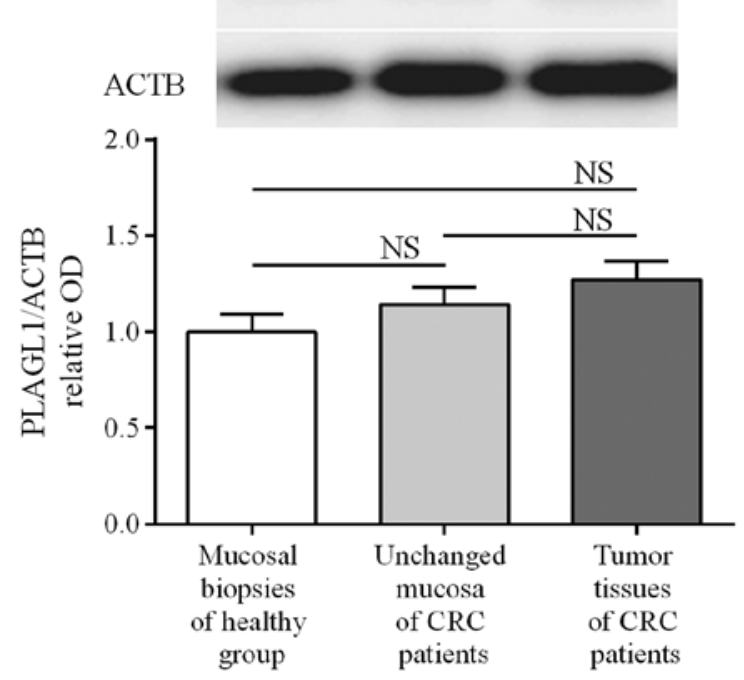

Figure 3. PLAGL1 protein levels in the tumor and unchanged large-intestine tissues of colorectal cancer patients and colon mucosal biopsies of healthy subjects. Representative blots of studied tissues are shown above the graph. $\beta$-actin (ACTB) was used as loading control. Bars represent mean \pm SEM. NS, differences not statistically significant $(\mathrm{p}>0.05)$.

age, tumor localization, TNM disease stage, depth of invasion, lymph node involvement, or the presence of metastases (p>0.05; Table II).

Heterogeneous expression of PLAGL1 protein in CRC tissues. To determine the expression of the PLAGLI gene at the protein level, matched tumor and unchanged tissues derived from CRC patients and colonic biopsies of healthy subjects were analyzed by western blotting. PLAGL1 protein was found in all studied tissues of CRC patients and in 30/32 (93.75\%) colonic biopsies of healthy subjects. The average content of PLAGL1 protein did not differ significantly between tumor and unchanged tissues of CRC patients or the colon mucosa of healthy individuals $(3.47 \pm 0.27$ vs. $3.12 \pm 0.24$ and $2.73 \pm 0.26$, respectively; p>0.05; Fig. 3). Among 95 tumor tissue specimens tested, the 
Table III. Associations between demographic and clinicopathological features of studied CRC patients and the relative PLAGL1 protein levels (assessed by western blotting) in colorectal tumor tissues.

\begin{tabular}{|c|c|c|c|c|c|c|c|}
\hline \multirow[b]{2}{*}{ Parameter } & \multirow[b]{2}{*}{$\begin{array}{l}\text { No. of } \\
\text { cases }\end{array}$} & \multirow[b]{2}{*}{$\begin{array}{l}\text { Percentage } \\
\quad(\%)\end{array}$} & \multicolumn{4}{|c|}{$\begin{array}{l}\text { PLAGL1 protein levels in tumor vs. } \\
\text { unchanged tissues of CRC patients }\end{array}$} & \multirow[b]{2}{*}{ p-values } \\
\hline & & & $\begin{array}{c}\text { Down } \\
(\text { ratio }<1)\end{array}$ & $\begin{array}{l}\text { Percentage } \\
\quad(\%)\end{array}$ & $\begin{array}{c}\mathrm{Up} \\
(\text { ratio }>1)\end{array}$ & $\begin{array}{l}\text { Percentage } \\
\quad(\%)\end{array}$ & \\
\hline Total & 95 & 100.0 & 47 & 49.5 & 48 & 50.5 & \\
\hline \multicolumn{8}{|l|}{ Gender } \\
\hline Male & 53 & 55.8 & 26 & 49.1 & 27 & 50.9 & 1.0000 \\
\hline Female & 42 & 44.2 & 21 & 50.0 & 21 & 50.0 & \\
\hline \multicolumn{8}{|l|}{ Age (years) } \\
\hline$\leq 67$ & 47 & 49.5 & 20 & 42.6 & 27 & 57.4 & 0.2204 \\
\hline$>67$ & 48 & 50.5 & 27 & 56.3 & 21 & 43.8 & \\
\hline \multicolumn{8}{|l|}{ Localization } \\
\hline $\begin{array}{l}\text { Cecum, ascending, } \\
\text { and transverse colon }\end{array}$ & 32 & 33.7 & 16 & 50.0 & 16 & 50.0 & 0.9931 \\
\hline $\begin{array}{l}\text { Descending and } \\
\text { sigmoid colon }\end{array}$ & 22 & 23.2 & 11 & 50.0 & 11 & 50.0 & \\
\hline Rectum & 41 & 43.2 & 20 & 48.8 & 21 & 51.2 & \\
\hline \multicolumn{8}{|l|}{$\begin{array}{l}\text { Depth of invasion } \\
\text { (pT status) }\end{array}$} \\
\hline $\mathrm{T} 1+\mathrm{T} 2$ & 17 & 17.9 & 7 & 41.2 & 10 & 58.8 & 0.5939 \\
\hline $\mathrm{T} 3+\mathrm{T} 4$ & 78 & 82.1 & 40 & 51.3 & 38 & 48.7 & \\
\hline \multicolumn{8}{|l|}{$\begin{array}{l}\text { Lymph nodes } \\
\text { (pN status) }\end{array}$} \\
\hline N0 & 52 & 54.7 & 19 & 36.5 & 33 & 63.5 & $0.0074^{\mathrm{a}}$ \\
\hline $\mathrm{N} 1+\mathrm{N} 2$ & 43 & 45.3 & 28 & 65.1 & 15 & 34.9 & \\
\hline \multicolumn{8}{|l|}{$\begin{array}{l}\text { Metastasis } \\
\text { (pM status) }\end{array}$} \\
\hline M0 & 81 & 85.3 & 35 & 43.2 & 46 & 56.8 & $0.0037^{\mathrm{a}}$ \\
\hline M1 & 14 & 14.7 & 12 & 85.7 & 2 & 14.3 & \\
\hline \multicolumn{8}{|l|}{ TNM stage } \\
\hline I + II & 49 & 51.6 & 16 & 32.7 & 33 & 67.3 & $0.0010^{\mathrm{a}}$ \\
\hline III+IV & 46 & 48.4 & 31 & 67.4 & 15 & 32.6 & \\
\hline
\end{tabular}

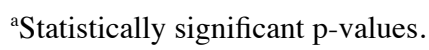

relative content of PLAGL1 protein (tumor tissue vs. matching unchanged mucosa of CRC patients) was downregulated in 47 $(49.5 \%)$ tumors while it was upregulated in $48(50.5 \%)$ cases (Table III).

Heterogeneous PLAGL1 immunohistochemical staining in CRC patient tissues. PLAGL1 immunoreactivity was observed in enterocytes (Fig. 4A) as well as cancer cells of the analyzed tissues (Fig. 4B, D, E, G, H and J-M). Immunoreactivity of the PLAGL1 protein was noted in cancer cells in $49 / 60(81.7 \%)$ of the analyzed CRC cases, whereas in enterocytes of unchanged large intestine tissue its expression was observed in 57/60 (95\%) cases. The average intensity of PLAGL1 immunostaining did not differ significantly between tumor and unchanged tissues of CRC patients $(18.5 \pm 2.07$ vs. $24.83 \pm 2.85$, respectively; $p>0.05)$. Among 60 tumor tissue specimens tested, the relative intensity of PLAGL1 staining was decreased in 27 (45\%) tumors and elevated in $15(25 \%)$ cases, while 18 (30\%) tumor samples demonstrated similar level of PLAGL1 immunoreactivity as cells of the corresponding unchanged tissues (Table IV).

Correlations between PLAGL1 protein content in CRC and demographic or clinicopathological features. Possible 

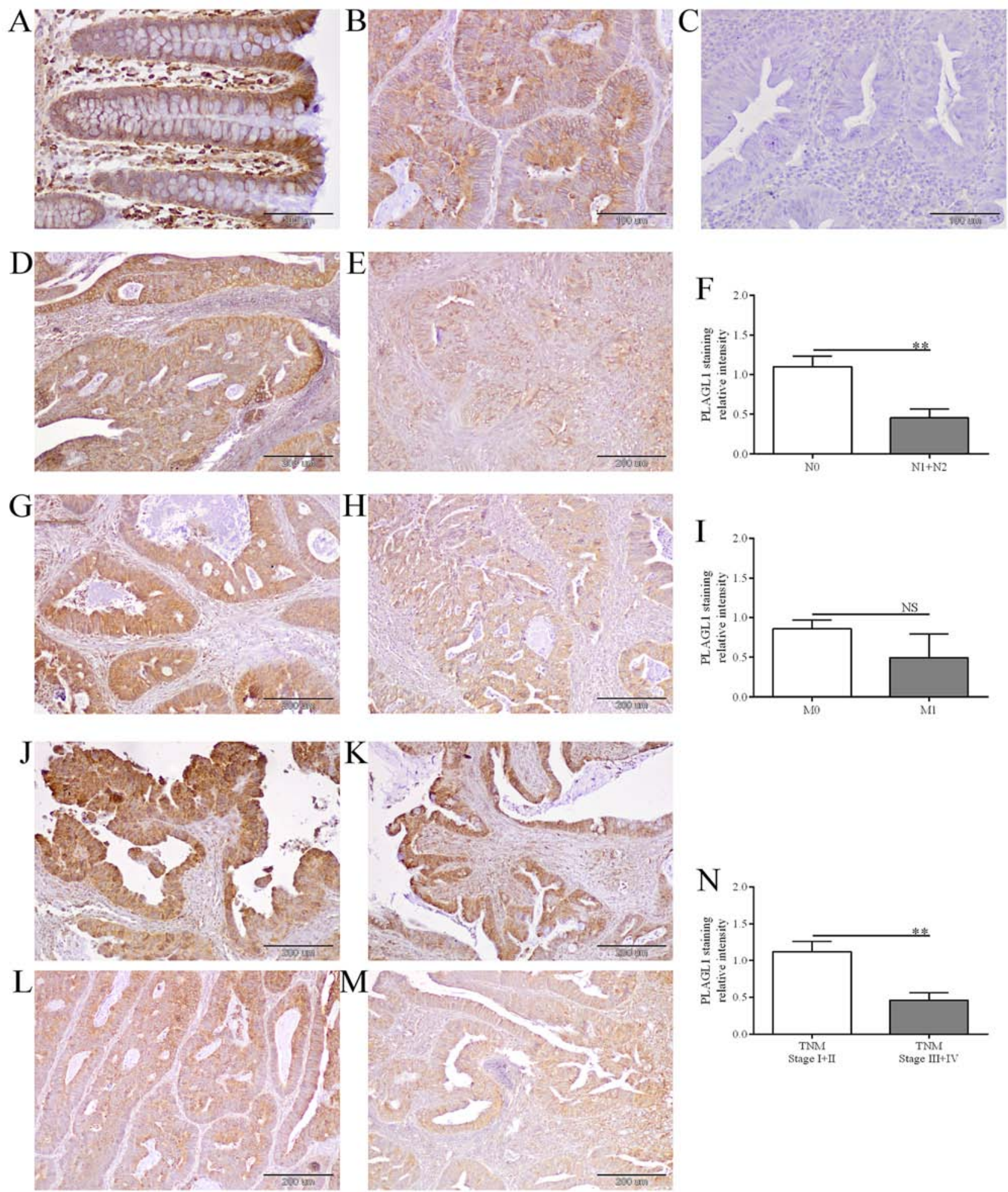

Figure 4. The evaluation of PLAGL1 protein expression in CRC and unchanged colorectal tissues by immunohistochemistry. Immunohistochemical staining of PLAGL1 protein in representative unchanged (A) and tumor (B) tissues of CRC patients. Negative controls were performed by omitting the primary antibody (C). Heterogeneous intensity of PLAGL1 staining depending on the lymph node involvement: N0 (D) and N1 (E), the presence of metastases: M0 (G) and M1 (H), and TNM disease stage: I (J), II (K), III (L) and IV (M). Magnification x200 (A-C) and x100 (D, E, G, H and J-M). The average immunoreactivity of the PLAGL1 protein in tumor specimens with regard to the lymph node involvement (F), the presence of metastases (I), and TNM disease stage (N); bars represent mean $\pm \mathrm{SEM} ;{ }^{* *} \mathrm{p}<0.01 ; \mathrm{NS}$, differences not statistically significant $(\mathrm{p}>0.05)$.

correlations of PLAGL1 expression at the protein level with selected demographic and clinicopathological parameters were analyzed based on the results obtained by western blot and immunohistochemical analyses. The relative PLAGL1 protein levels in tumor specimens did not correlate with the patient gender, age, tumor localization, and depth of invasion. However, PLAGL1 protein content was lower in tumor specimens derived from patients diagnosed with: i) lymph node involvement $[\mathrm{p}=0.0074$, the Fisher's exact test, Table III; confirmed by the Mann-Whitney U test: $1.66 \pm 0.18$ vs. $1.21 \pm 0.17$ 
Table IV. Associations between demographic and clinicopathological features of studied CRC patients and the relative PLAGL1 immunoreactivity in tumor cells.

\begin{tabular}{|c|c|c|c|c|c|c|c|}
\hline \multirow[b]{2}{*}{ Parameter } & \multirow[b]{2}{*}{$\begin{array}{l}\text { No. of } \\
\text { cases }\end{array}$} & \multirow[b]{2}{*}{$\begin{array}{l}\text { Percentage } \\
(\%)\end{array}$} & \multicolumn{4}{|c|}{$\begin{array}{l}\text { PLAGL1 immunoreactivity in tumor vs. } \\
\text { unchanged tissues of CRC patients }\end{array}$} & \multirow[b]{2}{*}{ p-values } \\
\hline & & & $\begin{array}{c}\text { Down } \\
(\text { ratio }<1)\end{array}$ & $\begin{array}{l}\text { Percentage } \\
\quad(\%)\end{array}$ & $\begin{array}{l}\mathrm{Up} \\
(\text { ratio }>1)\end{array}$ & $\begin{array}{l}\text { Percentage } \\
\quad(\%)\end{array}$ & \\
\hline Total $^{\mathrm{b}}$ & 42 & 100.0 & 27 & 64.3 & 15 & 35.7 & \\
\hline \multicolumn{8}{|l|}{ Gender } \\
\hline Male & 20 & 47.6 & 14 & 70.0 & 6 & 30.0 & 0.5311 \\
\hline Female & 22 & 52.4 & 13 & 59.1 & 9 & 40.9 & \\
\hline \multicolumn{8}{|l|}{ Age (years) } \\
\hline$\leq 67$ & 18 & 42.9 & 10 & 55.6 & 8 & 44.4 & 0.3465 \\
\hline$>67$ & 24 & 57.1 & 17 & 70.8 & 7 & 29.2 & \\
\hline \multicolumn{8}{|l|}{ Localization } \\
\hline $\begin{array}{l}\text { Cecum, ascending, } \\
\text { and transverse colon }\end{array}$ & 12 & 28.6 & 9 & 75.0 & 3 & 25.0 & 0.5802 \\
\hline $\begin{array}{l}\text { Descending and } \\
\text { sigmoid colon }\end{array}$ & 9 & 21.4 & 6 & 66.7 & 3 & 33.3 & \\
\hline Rectum & 21 & 50.0 & 12 & 57.1 & 9 & 42.9 & \\
\hline \multicolumn{8}{|l|}{$\begin{array}{l}\text { Depth of invasion } \\
\text { (pT status) }\end{array}$} \\
\hline $\mathrm{T} 1+\mathrm{T} 2$ & 7 & 16.7 & 3 & 42.9 & 4 & 57.1 & 0.2252 \\
\hline $\mathrm{T} 3+\mathrm{T} 4$ & 35 & 83.3 & 24 & 68.6 & 11 & 31.4 & \\
\hline \multicolumn{8}{|l|}{$\begin{array}{l}\text { Lymph nodes } \\
\text { (pN status) }\end{array}$} \\
\hline N0 & 24 & 57.1 & 11 & 45.8 & 13 & 54.2 & $0.0081^{\mathrm{a}}$ \\
\hline $\mathrm{N} 1+\mathrm{N} 2$ & 18 & 42.9 & 16 & 88.9 & 2 & 11.1 & \\
\hline \multicolumn{8}{|l|}{$\begin{array}{l}\text { Metastasis } \\
\text { (pM status) }\end{array}$} \\
\hline M0 & 38 & 90.5 & 24 & 63.2 & 14 & 36.8 & 1.0000 \\
\hline M1 & 4 & 9.5 & 3 & 75.0 & 1 & 25.0 & \\
\hline \multicolumn{8}{|l|}{ TNM stage } \\
\hline $\mathrm{I}+\mathrm{II}$ & 23 & 54.8 & 10 & 43.5 & 13 & 56.5 & $0.0031^{\mathrm{a}}$ \\
\hline III+IV & 19 & 45.2 & 17 & 89.5 & 2 & 10.5 & \\
\hline
\end{tabular}

${ }^{a}$ Statistically significant $\mathrm{p}$-values. ${ }^{\mathrm{b}}$ Tumor samples $(\mathrm{n}=18)$ showing the same intensity of immunostaining as cells of the corresponding unchanged tissue were excluded from this analysis.

(N0 vs. N1+N2), p=0.0122, Fig. 5A], ii) the presence of metastases $[\mathrm{p}=0.0037$, the Fisher's exact test, Table III; confirmed by the Mann-Whitney U test: $1.57 \pm 0.14$ vs. $0.80 \pm 0.16$ (M0 vs. M1), p=0.0309, Fig. 5B], and iii) a higher TNM disease stage $[\mathrm{p}=0.001$, the Fisher's exact test, Table III; confirmed by the Mann-Whitney U test: $1.73 \pm 0.19$ vs. $1.17 \pm 0.16$ (I+II vs. III+IV), p=0.0014, Fig. 5C].

Similarly, decreased intensity of PLAGL1 immunohistochemical staining in tumor specimens was associated with lymph node involvement $[\mathrm{p}=0.0081$, the Fisher's exact test, Table IV; confirmed by the Mann-Whitney U test: $1.10 \pm 0.14$ vs. $0.45 \pm 0.11$ (N0 vs. N1+N2), p=0.0020, Fig. 4D-F] and a higher TNM disease stage $[\mathrm{p}=0.0031$, the Fisher's exact test, Table IV; confirmed by the Mann-Whitney U test: $1.12 \pm 0.14$ vs. $0.46 \pm 0.10$ (I+II vs. III+IV), p=0.0014, Fig. $4 J-N]$.

Expression of the PLAGL1 gene and overall survival of the patients. To estimate the significance of the PLAGL1 expression level as a prognostic factor, all patients were followed up for 36.1 months. During this observation period, 43 (35.5\%) patients died.

The levels of PLAGL1 mRNA and protein expression, or the intensity of PLAGL1 immunostaining did not correlate significantly with the patient overall survival (Table V; 
Table V. Analysis of overall survival of CRC patients in relation to their demographic, clinicopathological and molecular characteristics.

\begin{tabular}{|c|c|c|c|c|c|}
\hline Parameter & Deaths/cases & Percentage (\%) & Hazard ratio & $95 \% \mathrm{CI}$ of $\mathrm{HR}$ & p-values \\
\hline \multicolumn{6}{|l|}{ Gender } \\
\hline Male & $23 / 67$ & 34.3 & 1.007 & $0.5530-1.833$ & 0.9823 \\
\hline Female & $20 / 54$ & 37.0 & $(1.00)$ & & \\
\hline \multicolumn{6}{|l|}{ Age (years) } \\
\hline$\leq 67$ & $13 / 60$ & 21.7 & 0.361 & $0.2055-0.6828$ & $0.0014^{\mathrm{a}}$ \\
\hline$>67$ & $30 / 61$ & 49.2 & $(1.00)$ & & \\
\hline \multicolumn{6}{|l|}{ Localization } \\
\hline $\begin{array}{l}\text { Cecum, ascending, } \\
\text { and transverse colon }\end{array}$ & $12 / 44$ & 27.3 & 0.691 & $0.3437-1.407$ & 0.3125 \\
\hline $\begin{array}{l}\text { Descending and } \\
\text { sigmoid colon }\end{array}$ & $12 / 29$ & 41.4 & 1.316 & $0.6286-2.829$ & 0.4541 \\
\hline Rectum & $19 / 48$ & 39.6 & $(1.00)$ & & \\
\hline \multicolumn{6}{|l|}{$\begin{array}{l}\text { Depth of invasion } \\
\text { (pT status) }\end{array}$} \\
\hline $\mathrm{T} 1+\mathrm{T} 2$ & $3 / 20$ & 15.0 & 0.325 & $0.2144-0.9916$ & $0.0477^{\mathrm{a}}$ \\
\hline $\mathrm{T} 3+\mathrm{T} 4$ & $40 / 101$ & 39.6 & $(1.00)$ & & \\
\hline \multicolumn{6}{|c|}{ Lymph nodes (pN status) } \\
\hline No & $12 / 63$ & 19.0 & 0.281 & $0.1579-0.5299$ & $<0.0001^{\mathrm{a}}$ \\
\hline $\mathrm{N} 1+\mathrm{N} 2$ & $31 / 58$ & 53.4 & $(1.00)$ & & \\
\hline \multicolumn{6}{|l|}{ Metastasis (pM status) } \\
\hline M0 & $30 / 106$ & 28.3 & 0.148 & $0.003700-0.04558$ & $<0.0001^{\mathrm{a}}$ \\
\hline M1 & $13 / 15$ & 86.7 & $(1.00)$ & & \\
\hline \multicolumn{6}{|l|}{ TNM stage } \\
\hline I & $2 / 18$ & 11.1 & 0.063 & $0.01695-0.1578$ & $<0.0001^{\mathrm{a}}$ \\
\hline II & $6 / 41$ & 14.6 & 0.084 & $0.004435-0.05342$ & $<0.0001^{\mathrm{a}}$ \\
\hline III & $22 / 47$ & 46.8 & 0.266 & $0.04809-0.3322$ & $<0.0001^{\mathrm{a}}$ \\
\hline IV & $13 / 15$ & 86.7 & $(1.00)$ & & \\
\hline \multicolumn{6}{|l|}{ PLAGL1 mRNA } \\
\hline Downregulated & $33 / 87$ & 37.9 & 1.448 & $0.7378-2.703$ & 0.2997 \\
\hline Upregulated & $10 / 34$ & 29.4 & $(1.00)$ & & \\
\hline \multicolumn{6}{|l|}{ PLAGL1 protein } \\
\hline Downregulated & $18 / 47$ & 38.3 & 1.585 & $0.7928-3.194$ & 0.1916 \\
\hline Upregulated & $14 / 48$ & 29.2 & $(1.00)$ & & \\
\hline \multicolumn{6}{|l|}{$\begin{array}{l}\text { PLAGL1 relative } \\
\text { immunoreactivity }\end{array}$} \\
\hline Downregulated & $11 / 27$ & 40.7 & 2.086 & $0.6393-5.651$ & 0.2482 \\
\hline Upregulated & $3 / 15$ & 20.0 & $(1.00)$ & & \\
\hline
\end{tabular}

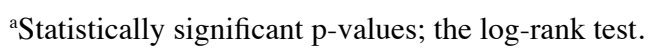

Fig. 6A-C); however, the hazard ratio (HR) for patients whose tumor tissues showed reduced immunostaining of the PLAGL1 protein was twice higher than in patients whose tumor tissues revealed increased PLAGL1 immunoreactivity (Table V). Of the analyzed demographic and clinicopathological parameters, advanced age at diagnosis ( $>67$ years; $\mathrm{p}=0.0014$; Table $\mathrm{V}$ and Fig. 6D), depth of invasion ( $\mathrm{p}=0.0477$; Table V and Fig. $6 \mathrm{E})$, lymph node involvement $(\mathrm{p}<0.0001$; Table V and Fig. $6 \mathrm{~F})$, the 

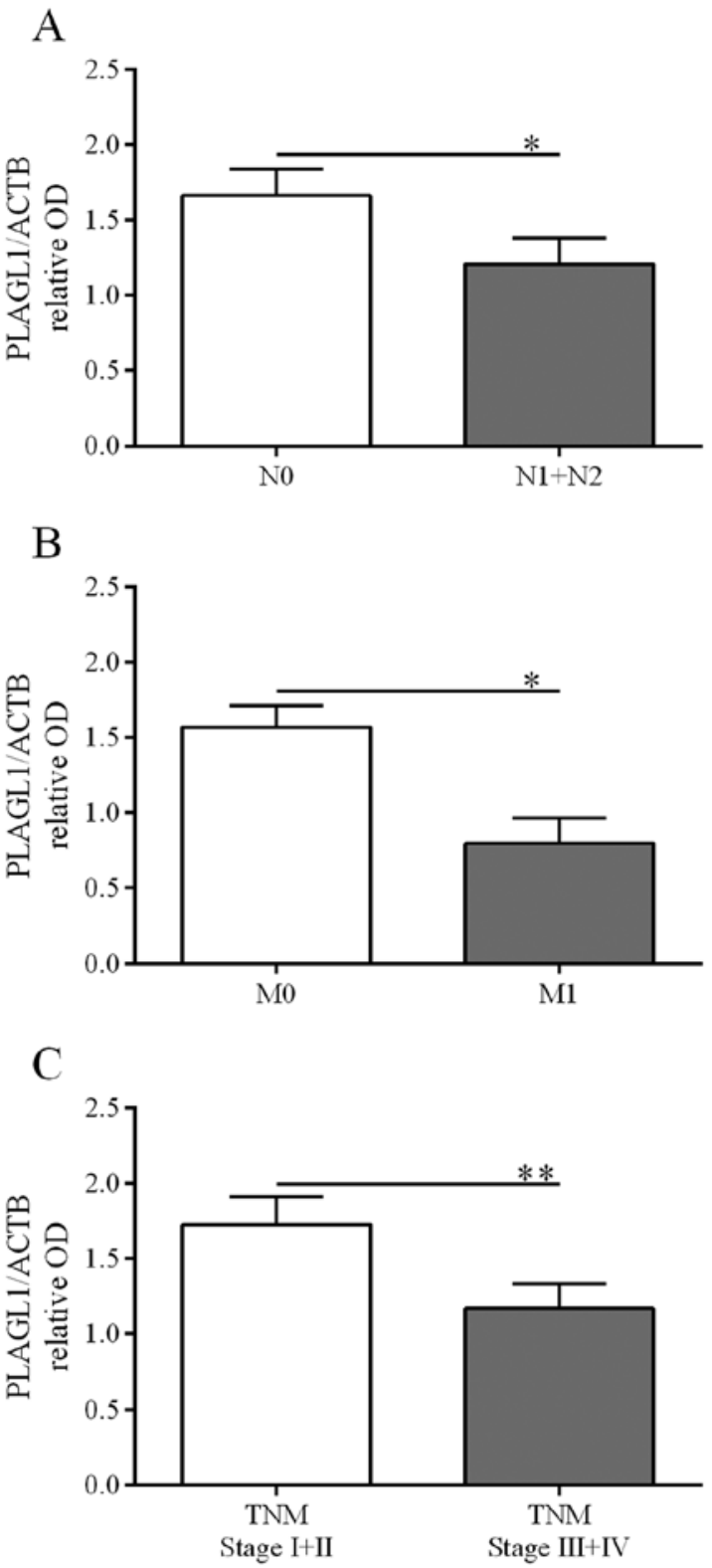

Figure 5. The relative expression of the PLAGL1 protein in tumor samples determined by western blot analysis in relation to the lymph node involvement (A), the presence of metastases (B), and TNM disease stage (C). Bars represent mean \pm SEM. ${ }^{*} \mathrm{p}<0.05,{ }^{* *} \mathrm{p}<0.01$.

presence of metastases ( $\mathrm{p}<0.0001$; Table $\mathrm{V}$ and Fig. 6G), and a high TNM disease stage ( $<0.0001$; Table V and Fig. $6 \mathrm{H})$ were associated with poor patient outcome.

\section{Discussion}

Allelic loss at long arm of chromosome 6 occurs in many types of human cancers, suggesting the presence of at least one tumor suppressor gene within this region $(8,9,18)$. The inactivation of tumor suppressor genes that control a variety of cellular processes including the cell cycle and apoptosis, can promote tumor formation. Genes which are differentially expressed in tumors as compared to healthy tissues may be considered as potential biomarkers for cancer detection, prognostic factors, or therapeutic targets. PLAGL1, localized at 6q24-q25, encodes a transcription factor with antiproliferative potential (19) and is ubiquitously expressed in normal tissues (5), with especially abundant expression shown in the pituitary and adrenal glands, as well as in the kidney (20). Expression of this gene was also confirmed in the colon tissue (20), therefore, we undertook the present study to compare the level of PLAGL1 expression in tissues of CRC patients and the healthy colon mucosa, and also to estimate its prognostic value. This is the first comprehensive report describing PLAGL1 expression in CRC and healthy colon tissues at both mRNA and protein levels, examined by the combination of three different techniques (qPCR, western blotting, and IHC), as well as in relation to demographic and clinicopathological features of CRC patients and their overall survival.

Previous studies revealed that PLAGL1 expression is frequently lost or decreased in several human cancer types (6-12); however, in the case of salivary gland tumors, Enlund et al (21) found no significant changes in the expression of this gene assessed at the mRNA level. We found PLAGL1 gene expression in all studied tissues of CRC patients and healthy subjects; however, $72 \%$ of CRC tumors showed decreased PLAGL1 mRNA levels. The results of our study are corroborated by the findings of Dai et al (13), who observed downregulated PLAGL1 expression in CRC using cDNA microarray. Our study is the first to report downregulated PLAGL1 gene expression in commonly used CRC cell lines as opposed to non-cancerous cells. Previous studies revealed undetectable or reduced levels of PLAGL1 mRNA in breast tumor cell lines (7), and human ovarian carcinoma cell lines (9). We observed the lowest level of PLAGL1 expression in the HT-29 cell line, which had been shown to have a high metastatic capacity (14). Xenografts, which were established by injection of HT-29 cells into mice, produced lymph node metastases in $83 \%$ of tumor-bearing animals (14). Moreover, the level of PLAGL1 mRNA was lower in the LoVo cell line in comparison to the SW-480 cells. The LoVo cell line corresponds to cells of Dukes' type C, grade IV, colorectal adenocarcinoma that was derived from metastatic site, whereas SW-480 cells are derived from Dukes' type B, colorectal adenocarcinoma (according to ATCC). These results suggest that downregulated PLAGL1 expression may be associated with the progression of CRC. In prostate cancer it was found that loss of PLAGLl expression is associated with progression from benign to metastatic prostate tumors (10).

So far, little is known about the clinical significance of the altered PLAGL1 expression in cancers. Our study failed to reveal any relationship between the level of PLAGL1 mRNA and clinicopathological and demographic features of the CRC patients. Interestingly, we found significant correlations between the reduced PLAGL1 protein content in CRC tissues and unfavorable clinical parameters. Although we detected no significant differences between the average content of PLAGL1 protein in samples of healthy colon mucosa and CRC, we observed significant downregulation of PLAGL1 protein expression in tumor specimens derived from patients diagnosed with lymph node involvement, the presence of metastases, and advanced TNM stage. These findings support the suppressor role of PLAGL1 and suggest that altered expression of PLAGL1 gene may promote progression of CRC. Moreover, our assumptions are in agreement with observa- 
A

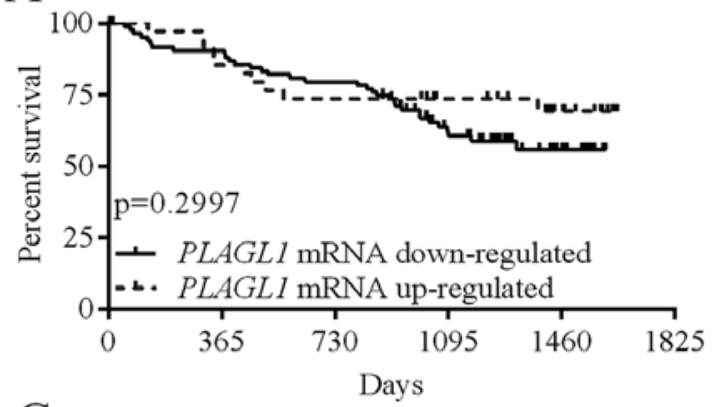

$\mathrm{C}$

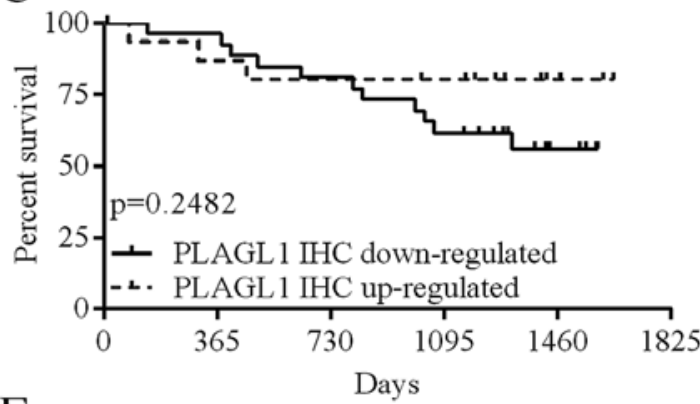

E

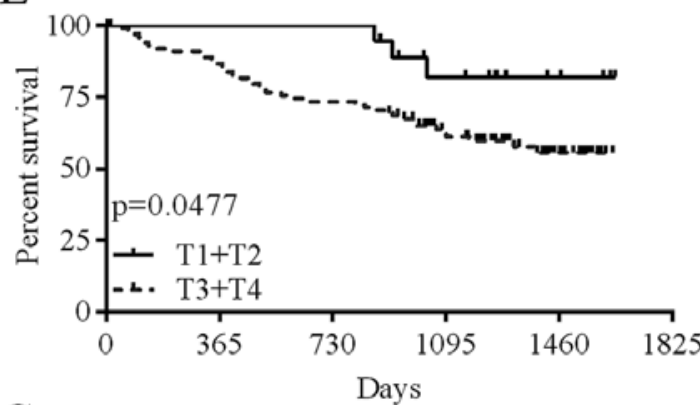

G

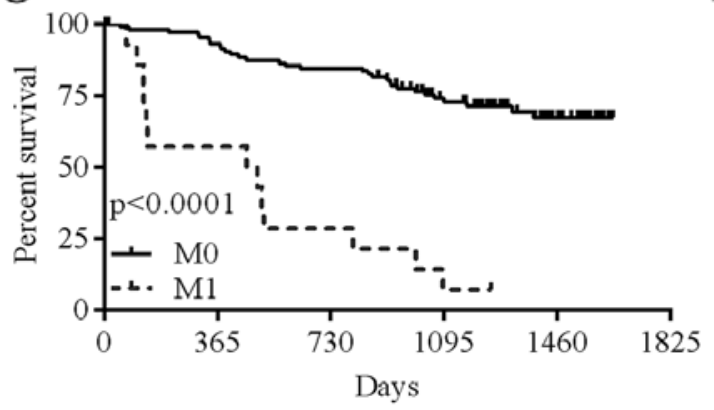

B

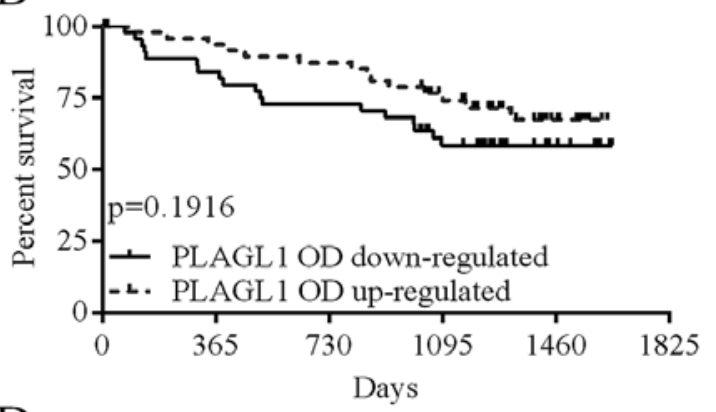

D

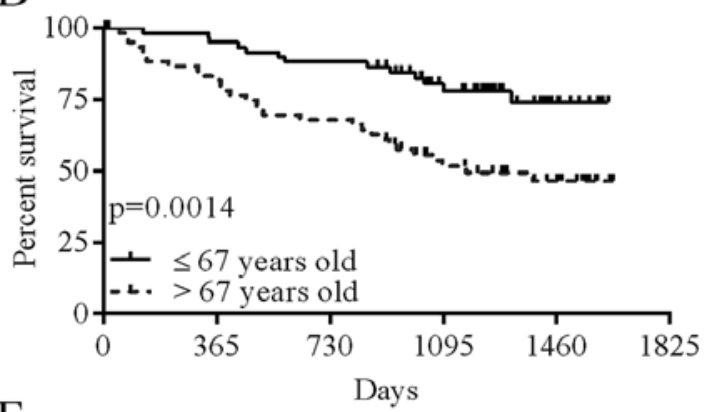

$\mathrm{F}$

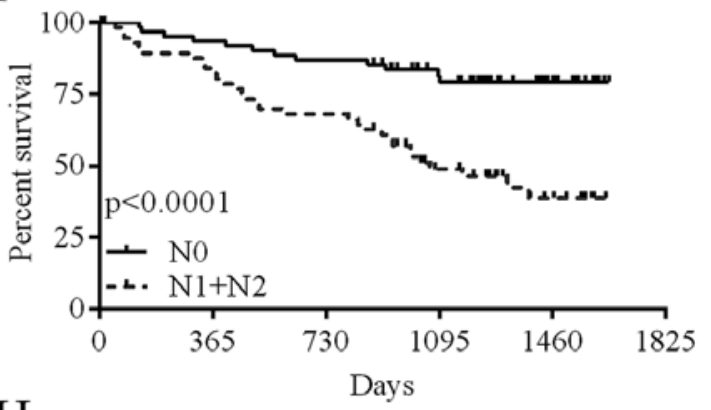

$\mathrm{H}$

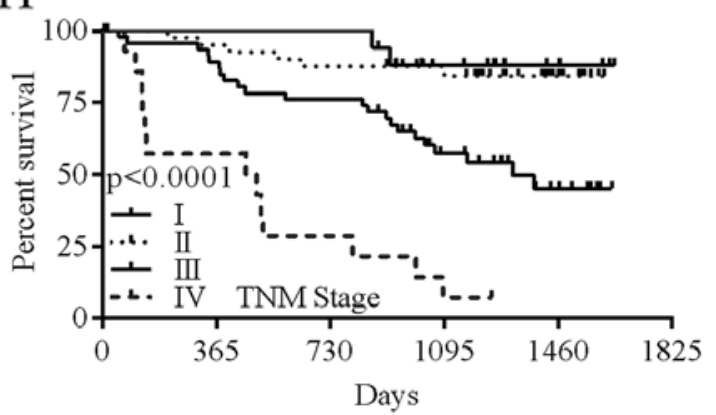

Figure 6. Analysis of overall survival of the patients. Kaplan-Meier survival curves of 121 colorectal cancer patients regarding the expression levels of PLAGL1 mRNA (A) and PLAGL1 protein levels (B), immunoreactivity of PLAGL1 protein (C), patients' age (D), depth of invasion (E), lymph node involvement (F), the presence of metastases $(\mathrm{G})$, and TNM disease stage $(\mathrm{H})$.

tions of Jarmalaite et al (22), who suggested an involvement of PLAGL1 loss in a more aggressive course of pheochromocytoma. Although we observed an increased hazard ratio for CRC patients with reduced intensity of PLAGL1 immunohistochemical staining of tumor tissue, the PLAGL1 expression level was not significantly correlated with overall survival of the patients. This may be partly due to the fact that the analysis of survival was limited by a relatively short period of follow-up.

We did not investigate mechanisms underlying the observed downregulation of PLAGL1 expression in CRC. Previous studies established that the transcriptional silencing of this gene may be regulated by epigenetic processes, such as meth- ylation of $\mathrm{CpG}$ islands and histone deacetylation (5). Moreover, it has been reported that downregulation of PLAGL1 expression may be mediated via epidermal growth factor receptor (EGFR) (4,23), which upon binding to its ligands activates signaling pathways that promote tumor growth, including cell invasion and metastasis $(24,25)$. EGFR has been reported to be overexpressed in CRC (26); furthermore, Cheirsilpa et al (27), using immunohistochemistry, demonstrated associations between overexpression of EGFR and lymph node status, as well as the advanced TNM stages. Our findings indicate analogous correlations between mentioned clinicopathological parameters and decreased PLAGL1 immunoreactivity in CRC 
tissues. These observations raise the hypothesis that cellular responses activated via the EGFR signaling cascade, such as proliferation, migration, and apoptosis, may be partially mediated by altered PLAGL1 expression. It has been also reported that the protein encoded by the PLAGLI gene may act as a regulator of nuclear receptor activity, including the glucocorticoid receptor (28), whose expression in colorectal cancer correlated with the expression of cell cycle-related molecules, such as Rb protein and p16 (29). Further studies are necessary to unveil mechanisms underlying the regulation of PLAGL1 expression in CRC and their implications for the role of the PLAGL1 protein in the pathogenesis of CRC.

In conclusion, the results of our study suggest that altered PLAGL1 expression, associated with unfavorable clinicopathological parameters, may be involved in the progression of colorectal cancer. However, the expression of PLAGL1 at the mRNA and protein levels failed to correlate with the patient survival. The latter calls into question the applicability of the PLAGL1 expression level as a prognostic factor in colorectal cancer until a longer period of follow-up will be available for survival analysis.

\section{Acknowledgements}

This study was supported by the National Science Centre grant no. NN402 452339.

\section{References}

1. Ferlay J, Soerjomataram I, Ervik M, Dikshit R, Eser S, Mathers C, Rebelo M, Parkin DM, Forman D and Bray F: GLOBOCAN 2012 v1.0, Cancer Incidence and Mortality Worldwide: IARC CancerBase No. 11. International Agency for Research on Cancer, Lyon, 2013. http://globocan.iarc.fr. Accessed Dec 01, 2014.

2. Boland CR, Shin SK and Goel A: Promoter methylation in the genesis of gastrointestinal cancer. Yonsei Med J 50: 309-321, 2009.

3. Spengler D, Villalba M, Hoffmann A, Pantaloni C, Houssami S, Bockaert $J$ and Journot L: Regulation of apoptosis and cell cycle arrest by Zac1, a novel zinc finger protein expressed in the pituitary gland and the brain. EMBO J 16: 2814-2825, 1997.

4. Abdollahi A: LOT1 (ZAC1/PLAGL1) and its family members: Mechanisms and functions. J Cell Physiol 210: 16-25, 2007.

5. Abdollahi A, Pisarcik D, Roberts D, Weinstein J, Cairns P and Hamilton TC: LOT1 (PLAGL1/ZAC1), the candidate tumor suppressor gene at chromosome 6q24-25, is epigenetically regulated in cancer. J Biol Chem 278: 6041-6049, 2003.

6. Basyuk E, Coulon V, Le Digarcher A, Coisy-Quivy M, Moles JP, Gandarillas A and Journot L: The candidate tumor suppressor gene $\mathrm{ZAC}$ is involved in keratinocyte differentiation and its expression is lost in basal cell carcinomas. Mol Cancer Res 3: 483-492, 2005.

7. Bilanges B, Varrault A, Basyuk E, Rodriguez C, Mazumdar A, Pantaloni C, Bockaert J, Theillet C, Spengler D and Journot L: Loss of expression of the candidate tumor suppressor gene ZAC in breast cancer cell lines and primary tumors. Oncogene 18: 3979-3988, 1999.

8. Cvetkovic D, Pisarcik D, Lee C, Hamilton TC and Abdollahi A: Altered expression and loss of heterozygosity of the LOT1 gene in ovarian cancer. Gynecol Oncol 95: 449-455, 2004.

9. Abdollahi A, Roberts D, Godwin AK, Schultz DC, Sonoda G, Testa JR and Hamilton TC: Identification of a zinc-finger gene at 6q25: A chromosomal region implicated in development of many solid tumors. Oncogene 14: 1973-1979, 1997.
10. Jacobs DI, Mao Y, Fu A, Kelly WK and Zhu Y: Dysregulated methylation at imprinted genes in prostate tumor tissue detected by methylation microarray. BMC Urol 13: 37, 2013.

11. Pagotto U, Arzberger T, Theodoropoulou M, Grübler Y, Pantaloni C, Saeger W, Losa M, Journot L, Stalla GK and Spengler D: The expression of the antiproliferative gene ZAC is lost or highly reduced in non-functioning pituitary adenomas. Cancer Res 60: 6794-6799, 2000.

12. Koy S, Hauses M, Appelt H, Friedrich K, Schackert HK and Eckelt U: Loss of expression of ZAC/LOT1 in squamous cell carcinomas of head and neck. Head Neck 26: 338-344, 2004.

13. Dai YC, Zhu XS, Nan QZ, Chen ZX, Xie JP, Fu YK, Lin YY, Lian QN, Sang QF and Zhan XJ: Identification of differential gene expressions in colorectal cancer and polyp by cDNA microarray. World J Gastroenterol 18: 570-575, 2012.

14. Flatmark K, Maelandsmo GM, Martinsen M, Rasmussen H and Fodstad Ø: Twelve colorectal cancer cell lines exhibit highly variable growth and metastatic capacities in an orthotopic model in nude mice. Eur J Cancer 40: 1593-1598, 2004.

15. Livak KJ and Schmittgen TD: Analysis of relative gene expression data using real-time quantitative PCR and the 2(-Delta Delta C(T)) method. Methods 25: 402-408, 2001.

16. Bradford MM: A rapid and sensitive method for the quantitation of microgram quantities of protein utilizing the principle of protein-dye binding. Anal Biochem 72: 248-254, 1976.

17. Schneider CA, Rasband WS and Eliceiri KW: NIH Image to ImageJ: 25 years of image analysis. Nat Methods 9: 671-675, 2012 .

18. Fujii H, Zhou W and Gabrielson E: Detection of frequent allelic loss of 6q23-q25.2 in microdissected human breast cancer tissues. Genes Chromosomes Cancer 16: 35-39, 1996.

19. Bilanges B, Varrault A, Mazumdar A, Pantaloni C, Hoffmann A, Bockaert J, Spengler D and Journot L: Alternative splicing of the imprinted candidate tumor suppressor gene ZAC regulates its antiproliferative and DNA binding activities. Oncogene 20: 1246-1253, 2001.

20. Varrault A, Ciani E, Apiou F, Bilanges B, Hoffmann A, Pantaloni C, Bockaert J, Spengler D and Journot L: hZAC encodes a zinc finger protein with antiproliferative properties and maps to a chromosomal region frequently lost in cancer. Proc Natl Acad Sci USA 95: 8835-8840, 1998.

21. Enlund F, Persson F and Stenman G: Molecular analyses of the candidate tumor suppressor gene, PLAGL1, in benign and malignant salivary gland tumors. Eur J Oral Sci 112: 545-547, 2004.

22. Jarmalaite $\mathrm{S}$, Laurinaviciene A, Tverkuviene J, Kalinauskaite $\mathrm{N}$, Petroska D, Böhling T and Husgafvel-Pursiainen K: Tumor suppressor gene ZAC/PLAGL1: Altered expression and loss of the nonimprinted allele in pheochromocytomas. Cancer Genet 204: 398-404, 2011.

23. Abdollahi A, Bao R and Hamilton TC: LOT1 is a growth suppressor gene down-regulated by the epidermal growth factor receptor ligands and encodes a nuclear zinc-finger protein. Oncogene 18: 6477-6487, 1999.

24. Schlessinger J: Cell signaling by receptor tyrosine kinases. Cell 103: 211-225, 2000.

25. Yarden Y: The EGFR family and its ligands in human cancer. signalling mechanisms and therapeutic opportunities. Eur J Cancer 37 (Suppl 4): S3-S8, 2001.

26. Spano JP, Lagorce C, Atlan D, Milano G, Domont J, Benamouzig R, Attar A, Benichou J, Martin A, Morere JF, et al: Impact of EGFR expression on colorectal cancer patient prognosis and survival. Ann Oncol 16: 102-108, 2005.

27. Cheirsilpa A, Ruangvejvorachai P, Karalak A, Sangprakarn S, Pummai S and Sangrajrang S: Determination of epidermal growth factor receptor (EGFR) in patients with colorectal cancer (Institutional series). Cancer Ther 5: 137-142, 2007.

28. Huang SM and Stallcup MR: Mouse Zac1, a transcriptional coactivator and repressor for nuclear receptors. Mol Cell Biol 20: $1855-1867,2000$

29. Theocharis S, Kouraklis G, Margeli A, Agapitos E, Ninos S, Karatzas G and Koutselinis A: Glucocorticoid receptor (GR) immunohistochemical expression is correlated with cell cyclerelated molecules in human colon cancer. Dig Dis Sci 48: 1745-1750, 2003. 